\title{
BOLILE MATERNE PREEXISTENTE - FACTOR DE RISC PENTRU ANOMALII CONGENITALE LA NOU-NĂSCUT
}

\author{
Elena Braha ${ }^{1}$, Alina-Costina Luca ${ }^{2}$ \\ ${ }^{\prime}$ Cabinetul de Genetică Medicală, Spitalul de Pediatrie „, Sf. Maria “, Iaşi \\ ${ }^{2}$ Clinica de Cardiologie Pediatrică, Spitalul de Pediatrie , Sf. Maria “, Iaşi
}

\begin{abstract}
REZUMAT
Anomaliile congenitale pot fi determinate de factori genetici, de mediu sau de combinația dintre cei doi factori. Bolile materne pot afecta dezvoltarea fetală prin acțiunea produşilor metabolici sau datorită transferului de anticorpi materni. Identificarea mamelor şi a sarcinilor cu risc, ca şi oferirea informațiilor despre riscul teratogen împreună cu o documentare adecvată asupra problemei au ca scop reducerea potențialului teratogen al bolilor materne.
\end{abstract}

Cuvinte cheie: boli materne, teratogen, anomalii congenitale

Anomaliile congenitale pot fi determinate de acțiunea prenatală a unor factori genetici, de mediu sau de o combinație a acestora. Se apreciază că aproximativ $10-15 \%$ dintre anomaliile congenitale sunt rezultatul acțiunii factorilor de mediu (intern sau extern) asupra dezvoltării fătului. (1) Acesta sugerează că aproximativ $1 / 250$ de nou-născuți prezintă anomalii congenitale datorate factorilor de mediu.

Teratogenii sunt reprezentați de orice agent (medicament, drog, substanță chimică, agent fizic, agent din mediu extern, infecții, boli materne) care determină o anomalie permanentă în structura sau funcția embrionului sau fătului, afectează creșterea sau determină decesul acestuia. (2)

Efectele agentului teratogen asupra embrionului sau fătului depind de natura agentului, dar şi de alți câțiva factori (doză, cale de administrare, durata expunerii, stadiul de dezvoltare embrionară în momentul expunerii, susceptibilitatea genetică a mamei şi a embrionului/fătului). În mod obişnuit, în primele două săptămâni de gestație agenții teratogeni distrug embrionul şi conduc la avort spontan. (3)

Unele femei pot avea probleme de sănătate anterioare momentului în care devin gravide, ceea ce poate conduce la complicații în timpul sarcinii. Bolile materne pot afecta dezvoltarea fătului prin câteva mecanisme: efectele specifice ale produşilor metabolici (produşi finali de metabolism toxici, producția maternă scăzută a unui anumit metabolit esențial) sau prin transfer de anticorpi.

\section{OBEZITATEA MATERNĂ}

Obezitatea mamei în timpul sarcinii este asociată cu efecte adverse cum ar fi macrosomia, hipertensiunea arterială, preeclampsia, diabet zaharat gestaţional şi deces al fătului. (4-6) Unele studii indică faptul că obezitatea maternă poate conduce la perturbarea dezvoltării şi maturării normale in utero a sistemului imun al fătului. (7) Alte studii au avut în vedere copiii mamelor obeze, aceştia având o dezvoltare temporar accelerată a cogniţiei şi limbajului, urmată de un declin rapid până la vârsta de 18 luni, în special în ceea ce priveşte limbajul. (8)

\section{DIABETUL ZAHARAT}

Hiperglicemia conduce la inhibarea recaptării inozotolului, ceea ce este esențial pentru mitozele embrionare şi dezvoltarea tubului neural. $(9,10)$ Proteina A plasmatică asociată sarcinii pare să fie un biomarker pentru diabetul matern şi nou-născutul cu greutate mare la naştere. (11)

Unele studii notează o corelaţie între creşterea HbAlc şi incidenţa anomaliilor congenitale majore la nou-născutul unei mame cu diabet zaharat. $(12,13)$ HbA1c care depăşeşte $11,5 \%$ este asociată cu anomalii congenitale la $66 \%$ dintre urmaşi: 
transpoziție de vase mari, defect septal ventricular (DSV) şi dextrocardia sunt cele mai comune anomalii congenitale de cord, anencefalia, spina bifida şi hidrocefalia sunt malformațiile majore ale sistemului nervos central. (14)

Se pare că diabetul zaharat matern afectează modelul de expresie temporară al genelor ce codifică molecule implicate în dezvoltarea cordului. (15)

Malformațiile rare includ situs inversus şi displazie caudală, anomalii vertebrale şi renale, imperforație de anus, aplazie de radius, agenezie şi displazie renală, alte defecte. Sindromul de displazie caudală, cu grade variabile de agenezie sacrată, este asociat ocazional cu defecte ale palatului şi ale arcurilor branhiale şi apare la 1\% dintre copiii mamelor diabetice. $(16,17)$ În anul 2015, Xiang A.H. et al au sugerat o corelație între diabetul zaharat matern şi spectrul bolii autiste. (18)

\section{BOLILE TIROIDIENE}

Bolile tiroidiene sunt frecvente în populația generală, mai întâlnite la femei şi e de aşteptat să apară mai frecvent în cursul sarcinii. Hipotiroidia maternă este, în general, datorată bolii autoimune tiroidiene. Unle rezultate arată diferențe semnificative în ceea ce priveşte IQ copiilor mamelor care au prezentat în cursul sarcinii hipotiroidie subclinică nediagnosticată, copilul depinzând în întregime de hormonii tiroidieni materni în primele 12 săptămâni de sarcină, până când apare tiroida fetală. (19)

Hipotiroidia netratată este asociată cu greutate mică la naştere şi un risc crescut de avort spontan şi mortalitate perinatală. (20) Hipotiroidia maternă şi fetală apar împreună mai ales în regiunile cu deficit de iod în dietă. Hipertiroidia în cursul sarcinii se datorează adesea bolii Basedow Graves. Tirotoxicoza neonatală este tranzitorie, având o durată de câteva luni, dar copilul afectat poate prezenta guşă, exoftalmie, agitație, tahicardie, edem periorbitar, apetit crescut, hipertermie, cardiomegalie, insuficiență cardiacă şi hepatospenomegalie. (21)

\section{HIPOPARATIROIDISM}

Hipocalcemia cronică este mai puțin frecventă decât hipercalcemia. Cauzele includ insuficiența renală cronică, hipoparatiroidismul congenital sau dobândit, deficitul de vitamină $\mathrm{D}$, pseudo-hipoparatiroidismul şi hipomagnesemia. Nu există un plan terapeutic bine stabilit pentru hipoparatiroidismul din cursul sarcinii deoarece unele studii pe animale au sugerat un posibil efect toxic fetal dependent de doză (de exemplu, afectarea creşterii, malformații scheletice şi anomalii cardiovasculare). (22)

Copiii mamelor cu hipoparatiroidism netratat şi calcemie scăzută pot avea hiperplazia paratiroidelor şi hiperparatiroidism trecător în perioada fetală sau neonatală. Hiperparatiroidismul congenital trebuie luat în considerare la nou-născuții cu detresă respiratorie, deformări toracice, demineralizare osoasă şi resorbție periostală de-a lungul oaselor lungi, stenoză de arteră pulmonară, defect septal ventricular (DSV) şi hipotonie musculară. $(23,24)$

\section{DEFICITUL NUTRIȚIONAL}

Deficitul în folați poate conduce la anomalii congenitale (defecte de tub neural, despicături labio-maxilo-faciale, anomalii cardiace), anemie şi avorturi spontane, preeclampsie şi retard în creşterea intra-uterină. Suplimentarea preconcepțională $\mathrm{cu}$ acid folic $(400 \mu \mathrm{g} / \mathrm{zi})$ previne defectele de tub neural. (25) Dozele crescute de acid folic administrare precoce în cursul sarcinii reduc, de asemenea, riscul de DSV. (26) Totuşi, unele studii experimentale susțin ideea că acidul folic administrat în cursul primelor săptămâni de sarcină este legat de modificări epigenetice în ADN-ul fetal, conducând la creşterea riscului de a dezvolta alergii şi astm în copilărie. (27) Alte studii au sugerat faptul că expunerea maternă la folați nu este asociată cu alergiile din copilărie. (28) Deficitul matern în fier are o influenţă directă asupra rezervelor neonatale de fier şi asupra greutății la naştere. Acest deficit poate conduce la apariţia problemelor cognitive şi de comportament în copilărie. Deficitul de calciu este asociat cu preeclampsia şi restricția creşterii intrauterine. (25)

Ipoteza DNA polymorphism-diet-cofactor-development (DDCD - polimorfismul $\mathrm{ADN}$ - cofactor dietetic - dezvoltare) susține faptul că schizofrenia se datorează anomaliilor creierului fetal, anomalii determinate de interacțiunea dintre mutațiile genice materne şi cofactorii nutriţionali (de exemplu, folați, cobalamină sau piridoxină) care sunt deficitari în dieta maternă. (29) Acidul retinoic, metabolitul activ al vitaminei A, joacă un important rol de semnalizare în cursul embriogenezei. Este bine cunoscut faptul că atât excesul, cât şi defícitul de vitamină A conduce la malformații congenitale incluzând malformații oculare cum ar fi gene rudimentare, microftalmie, exoftalmie, anomalii ale urechii externe (microție, anoție), anomalii cardiovasculare (hipoplazie cardiacă, persistența canalului arterial, transpoziție de vase mari), hernie diafragmatică, testicul necoborât. (30) Statusul nutrițional matern 
deficitar, de exemplu femeile indiene cronic subnutrite care au un aport mic sau nul de proteine animale în primul trimestru de sarcină au avut copii cu greutate mare la naştere. (31)

\section{BOLILE AUTOIMUNE. LUPUSUL SISTEMIC ERITEMATOS}

Lupusul sistemic eritematos (LSE) este o boală inflamatorie autoimună sistemică care afectează tegumentele şi sistemul musculoscheletic matern ca şi pe cel al fătului. LSE este caracterizată prin hiperactivitate imună cu formarea de anticorpi patogeni. De exemplu, avortul precoce din primul trimestru de sarcină este asociat cu anticorpi antifosfolipidici materni care includ anticorpi anticoagulanţi de tip lupic şi anticorpi anticardiolipină. LSE este, de asemenea, asociat cu creşterea frecvenței preeclampsiei, prematurității, retard în dezvoltare cu nou-născut mic pentru vârstă gestațională. Sindromul de lupus neonatal (nou-născut cu anomalii dermatologice, cardiace şi hepatice) este datorat transferului pasiv al anticorpilor anti-Ro/ SSA şi anti-La/SSB (anticorpi antinucleari) la unii copii ai mamelor afectate de boli autoimune. Manifestările cardiace includ anomalii de conducere (bloc atriventricular de grad I, II sau III), fibroelastoză endocardică şi cardiomiopatie. $(32,33)$

\section{MIASTENIA GRAVIS}

Miastenia gravis este o boală mediată imun, determinată de anticorpi serici ce se leagă de receptorul nicotinic pentru acetilcolină (anticorpi antiAchR), receptor esențial pentru transmiterea neuromusculară, conducând la slăbiciune musculară progresivă şi oboseala musculaturii voluntare. Unele studii au arătat că transferul transplacentar de anticorpi materni anti AchR la făt poate determina un risc crescut de avort spontan sau naştere prematură sau, la 10\% dintre nou-născuți, miastenia-gravis neonatală trecătoare cu hipotonie, detresă respiratorie şi dificultăţi de alimentație ce se rezolvă de obicei în 4-6 săptămâni. În unele cazuri s-au raportat contracturi congenitale multiple la nou-născut, dismor- fie craniofacială, edem cutanat, cifoză/scolioză, pterigii multiple şi urechi jos inserate. $(34,35)$

\section{FENILCETONURIA}

Fenilcetonuria este o boală rară ce afectează metabolismul fenilalaninei, transmisă autosomal recesiv, asociată cu concentrații plasmatice crescute de fenilalanină mai mari de $1.000 \mu \mathrm{mol} / \mathrm{L}$. Fenilalanina are efect teratogen în cursul sarcinii, determinând retard al creşterii intrauterine şi postnatale, microcefalie, deficit intelectual, defecte cardiovasculare (ventricul drept cu dublă cameră de ieşire, tetralogie Fallot şi defect septal ventricular). $(36,37)$ Concentrația optimă de fenilalanină maternă trebuie strict menținută pe tot parcursul sarcinii pentru a reduce riscul de anomalii congenitale. (38)

\section{FEBRA MATERNĂ ÎN PRIMUL TRIMESTRU DE SARCINĂ}

Defectele de tub neural (anencefalia, spina bifida, encefalocelul) au o etiologie complexă, implicând atât factori genetici, cât şi factori de mediu. $(39,40)$ Unele studii au indicat faptul că purtătorii genei ce reduce metabolismul folatului (SLC19A1) sunt asociaţi cu creşterea riscului de defecte de tub neural (DTN). Riscul pentru DTN este influențat de interacțiunea dintre varianta genică SLC19A1 (rs1051266 GG/GA) şi febra maternă din primul trimestru de sarcină. (41)

\section{CONCLUZII}

În concluzie, cunoaşterea teratogenilor umani oferă posibilitatea de a preveni unele tipuri de malformații congenitale. Acest studiu demonstrează continua necesitate de a evalua statusul de sănătate al mamei atunci când avem de a face cu copii cu anomalii congenitale. Identificarea mamelor şi a sarcinilor cu risc, precum şi discuţiile despre riscul teratogen şi oferirea documentației corespunzătoare au ca scop reducerea potențialului teratogen al bolilor materne. 